\title{
Chronic enterococcal spinal implant infection 6 years after instrumentation of a severe scoliosis in a 22-year-old woman
}

\author{
Emilie Virot, ${ }^{1}$ Cédric Barrey, ${ }^{1,2}$ Christian Chidiac, ${ }^{1,2,3}$ Tristan Ferry, $^{1,2,3}$ on behalf \\ of the Lyon Bone and Joint Infection Study group
}

\begin{abstract}
${ }^{1}$ Hospices Civils de Lyon, Lyon, France

2Université Claude Bernard Lyon 1, Lyon, France ${ }^{3}$ Centre International de Recherche en Infectiologie, CIRI, Inserm U1111, CNRS UMR5308, ENS de Lyon, UCBL1, Lyon, France
\end{abstract}

\section{Correspondence to}

Dr Tristan Ferry,

tristan.ferry@univ-lyon1.fr

Accepted 8 May 2015
CrossMark

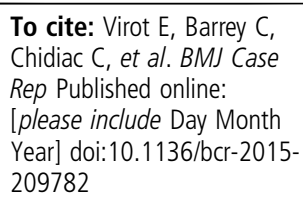

\section{DESCRIPTION}

A 22-year-old woman with severe double curve scoliosis was instrumented in 2006 (posterior instrumentation T2-L5). In 2007-2008, the patient had progressive worsening of the scoliosis. In August 2012, she presented with mild oozing matter from the surgery scar in the middle of her back (figure 1A). There was no pain. Her $\mathrm{C}$ reactive protein level was $1 \mathrm{mg} / \mathrm{L}$ in plasma. There was no reason to consider other sites of infection. Spinal $\mathrm{X}$-rays showed failure of surgery for correction of sagittal imbalance with worsening of the spinal deformity, implant migration and implant loosening at the lower part of the instrumentation (figure 1B). Late postoperative spinal implant infection with fistula was diagnosed. Total explantation of the instrumentation (including the 2 rods and the hooks) with wide debridement was performed, and abscesses, detected close to each hook, were drained. Surgical samples grew Enterococcus faecalis. The patient received high doses of intravenous amoxicillin for 1 month and amoxicillin orally for 4 months thereafter. No pain remained and the spinal deformity has not worsened at 2-year follow-up.

Treatment of spinal implant infection is challenging, and late enterococcal spinal implant-related
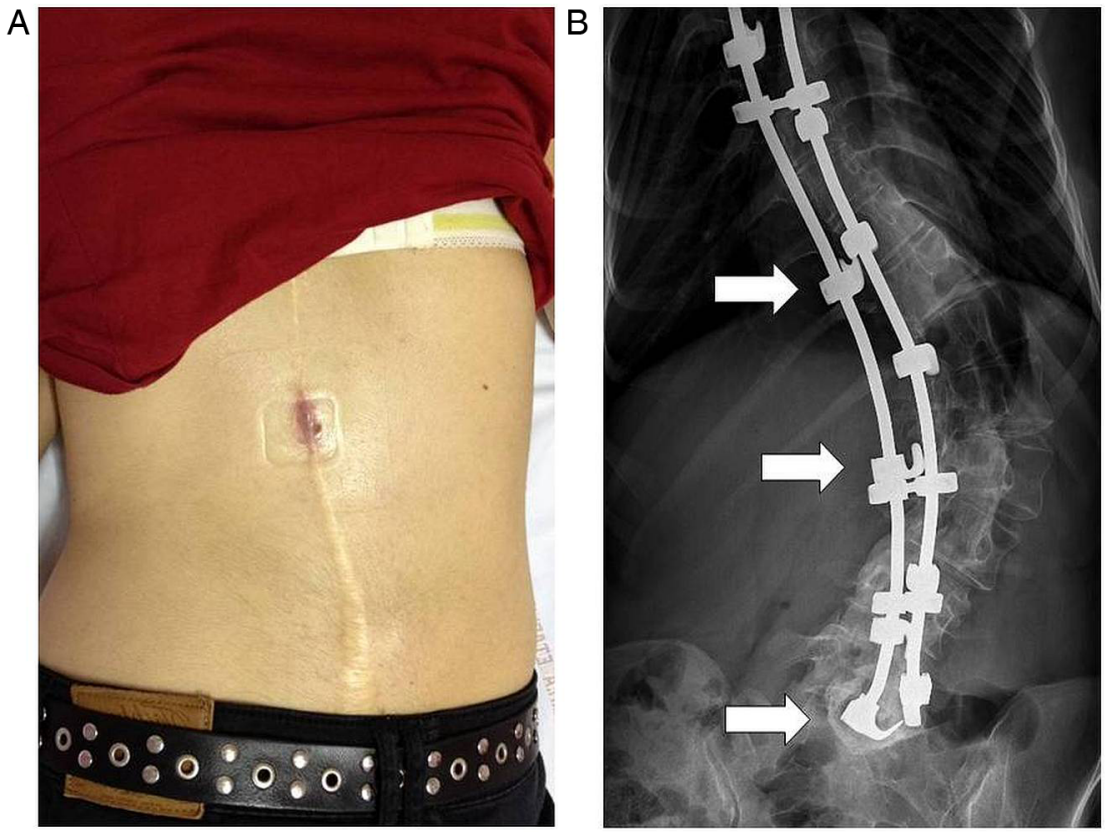

Figure 1 (A) Fistula in the scar on the middle of the back. (B) X-ray showing loss of correction and implant migration implant loosening at L5 (arrows showing hook loosening).

infections are poorly described. ${ }^{1}$ Surgical debridement, implant retention and a 3-month antibiotic therapy have been proposed for acute infection $\left(<1\right.$ month). ${ }^{2}$ However, the duration of antimicrobial therapy for chronic implant infection is unknown. For patients in whom the material has not been totally removed, long-term suppressive antimicrobial therapy is usually proposed. ${ }^{1}$ Whereas, for those patients in whom the material has been totally removed, an antibiotic therapy $<6$ months is probably sufficient, as is proposed for lower limb implant-associated bone and joint infections such as of the prosthetic joint. ${ }^{3}$

\section{Learning points}

Enterococcus faecalis could be responsible for chronic postoperative spinal implant infection.

- Fistula is often associated with implant migration and loosening.

- The duration of antimicrobial therapy should be $<6$ months in patients with chronic postoperative spinal implant infection and in whom the material has been completely removed. 
Acknowledgements Lyon Bone and Joint Infection Study Group: PhysiciansTristan Ferry, Thomas Perpoint, André Boibieux, François Biron, Florence Ader, Julien Saison, Florent Valour, Fatiha Daoud, Johanna Lippman, Evelyne Braun, Marie-Paule Vallat, Patrick Miailhes, Christian Chidiac, Dominique Peyramond; Surgeons - Sébastien Lustig, Philippe Neyret, Olivier Reynaud, Caroline Debette, Adrien Peltier, Anthony Viste, Jean-Baptiste Bérard, Frédéric Dalat, Olivier Cantin, Romain Desmarchelier, Michel-Henry Fessy, Cédric Barrey, Francesco Signorelli, Emmanuel Jouanneau, Timothée Jacquesson, Pierre Breton, Ali Mojallal, Fabien Boucher, Hristo Shipkov; Microbiologists—Frederic Laurent, François Vandenesch, Jean-Philippe Rasigade, Céline Dupieux; Imaging — Loïc Boussel, Jean-Baptiste Pialat; Nuclear Medicine —-Isabelle Morelec, Marc Janier, Francesco Giammarile; PK/PD specialists—Michel Tod, Marie-Claude Gagnieu, Sylvain Goutelle; Clinical Research Assistant-Eugénie Mabrut.

Contributors EV wrote the case. TF, CB and CC participated in the literature review and edited the manuscript.
Competing interests None declared.

\section{Patient consent Obtained.}

Provenance and peer review Not commissioned; externally peer reviewed.

\section{REFERENCES}

1 Garg S, LaGreca J, Hotchkiss $\mathrm{M}$, et al. Management of late (>1 y) deep infection after spinal fusion: a retrospective cohort study. J Pediatr Orthop 2015;35:266-70.

2 Dubée $V$, Lenoir $T$, Leflon-Guibout $V$, et al. Three-month antibiotic therapy for early-onset postoperative spinal implant infections. Clin Infect Dis 2012;55:1481-7.

3 Osmon DR, Berbari EF, Berendt AR, et al, Infectious Diseases Society of America. Diagnosis and management of prosthetic joint infection: clinical practice guidelines by the Infectious Diseases Society of America. Clin Infect Dis 2013;56:e1-e25.

Copyright 2015 BMJ Publishing Group. All rights reserved. For permission to reuse any of this content visit http://group.bmj.com/group/rights-licensing/permissions.

BMJ Case Report Fellows may re-use this article for personal use and teaching without any further permission.

Become a Fellow of BMJ Case Reports today and you can:

- Submit as many cases as you like

- Enjoy fast sympathetic peer review and rapid publication of accepted articles

- Access all the published articles

- Re-use any of the published material for personal use and teaching without further permission

For information on Institutional Fellowships contact consortiasales@bmjgroup.com

Visit casereports.bmj.com for more articles like this and to become a Fellow 